\title{
A Report on Socio-Economic Status in Villages of the Panshet Dam Catchment Region
}

\author{
Yogesh Pathak \\ The author is a management consultant and volunteer at Ecological Society. \\ Email : yp1227@gmail.com
}

\begin{abstract}
In 1985, Ecological Society had conducted a detailed ecological and socio-economic survey of the Panshet dam catchment region near Pune. In 2014, thanks to a grant from Global Forest Watch, a detailed ecological survey was repeated for the region. A dipstick study was also conducted across six villages to assess the current socio-economic aspects and man-nature relationship in the region. Data on population, households, occupations, income, land use, agricultural practices, cattle, vegetation, forest resources, schools and other amenities, and social bonds was collected. These findings were compared with the 1985 study to assess ongoing changes in the catchment. We found that the process of degradation of forests has continued. As a result, the worsening of human-nature relationship has also continued. Decline in agriculture, lack of profits in ancillary occupations, migration out of the catchment, and land acquisition by urban property owners and developers, complicate the region's socioeconomic picture. Many of the 1985 study recommendations, if implemented with good governance, had the potential to nurture a sustainable, natural resource-centric economy in the region, however this did not happen. Going forward, a landscape ecological approach, managed by a quasi-government Catchment Authority, is suggested. The report makes recommendations for new implementation vehicles, such as a Model Eco-Sensitive Zone Initiative, a Landowner-Conservators' Collective, an Incubator for Sustainable Local Economy, and a Reverse Migration Program.
\end{abstract}

\section{Introduction}

Socio-economic studies from an ecological standpoint are designed to collect data to inter-relate status of ecosystems, land use, natural resources, vegetation, and biodiversity with human needs and actions. Such studies often include multiple objectives like assessment of :

1. Energy demand and its sources, food, forest resources, water demand and sources, land use, agricultural inputs, soil quality.

2. Occupations and livelihood in and of the community.

3. Migration of locals to the city from rural areas.

4. The local economy and its integration with urban economy

5. Health, happiness, and well-being

6. Man-nature relationship

7. Local problems and key demands of local populations
In 1985, Ecological Society had conducted a detailed ecological and socio-economic survey of the Panshet dam catchment region near Pune (Gole, 1985). Several villages in the catchment of river Ambi were submerged under the reservoir when the Panshet dam was built during 1957-61. These villagers could not be successfully rehabilitated in far-off alternative locations like Daund, and few came back to resettle on slopes in the Panshet catchment. Located on the middle contours of Western Ghats (altitude $2500 \mathrm{ft}$ ), these 23 settlements comprised the study region of $\sim 120$ sq. km. The 1985 survey had studied the land use, occupations, natural resource use, economic status, and amenities of these communities in great detail.

In 2014, Ecological Society undertook an ecological survey in Panshet Catchment and Bhimashankar Wildlife Sanctuary of Western Ghats. While socioeconomic analysis was not a major objective of the survey, a dipstick study was undertaken to help us relate ecological survey findings with socio-economic 
changes in the region. This report summarizes the key findings of this 2014 study and provides comparison to the 1985 study. The study was undertaken with a questionnaire template of 55 questions. Eight families/ individuals across six villages (See Table 1) in the catchment area were interviewed. This data, coupled with discussions with other practitioners frequently visiting this area, forms the basis of our findings.

The author considered it important to compare the current data with that of the 1985 study for the following reasons :

- The 30 year period would allow an assessment of long-term socio-ecological changes or patterns in the region.

- A comprehensive study similar to (Gole, 1985) was also reported by (Brahme, 1986). Other than these two studies we have not come across any similar socio-ecological studies done in this region during the period from 1985 to 2015 .

This study was a short and exploratory one and is not as exhaustive or comprehensive as (Gole, 1985) or (Brahme, 1986).
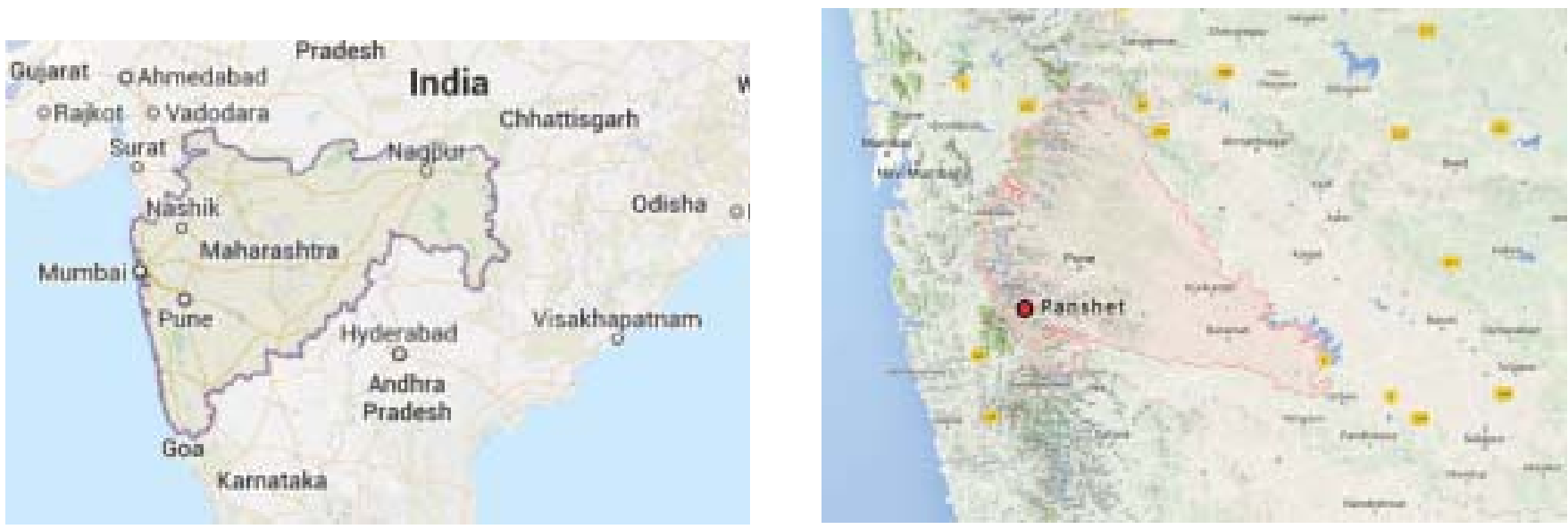

Figure 1: Location map of Panshet w.r.t state of Maharashtra and the Pune district

\section{The Study Region}

The Panshet dam, built on river Ambi, is located 40k.m. west of the city of Pune. The catchment of the river Ambi up to the dam wall is spread over 118 sq. $\mathrm{km}$. across multiple rainfall zones in the Northern Western Ghats.

The lat-long range for the catchment is $73^{\circ} 26^{\prime} 7.947^{\prime \prime} \mathrm{E}$ and $18^{\circ} 17^{\prime} 43.641^{\prime \prime} \mathrm{N}$ to $73^{\circ} 37^{\prime} 44.686^{\prime \prime} \mathrm{E}$ and $18^{\circ} 23^{\prime} 14.33^{\prime \prime} \mathrm{N}$ with elevations ranging from $626 \mathrm{~m}$ at valley to $1134 \mathrm{~m}$ at the ridge line (Pole village). The reservoir itself is a little over $14 \mathrm{sq} . \mathrm{km}$. The chart below shows the relative location of the Panshet catchment w.r.t the state of Maharashtra.

\section{Key Socio-economic Findings}

1. Population and Households: Owing to migration to large cities and to Panshet colony over the past 30 years, the population and households in the villages has mostly declined. This is more pronounced in smaller villages. 


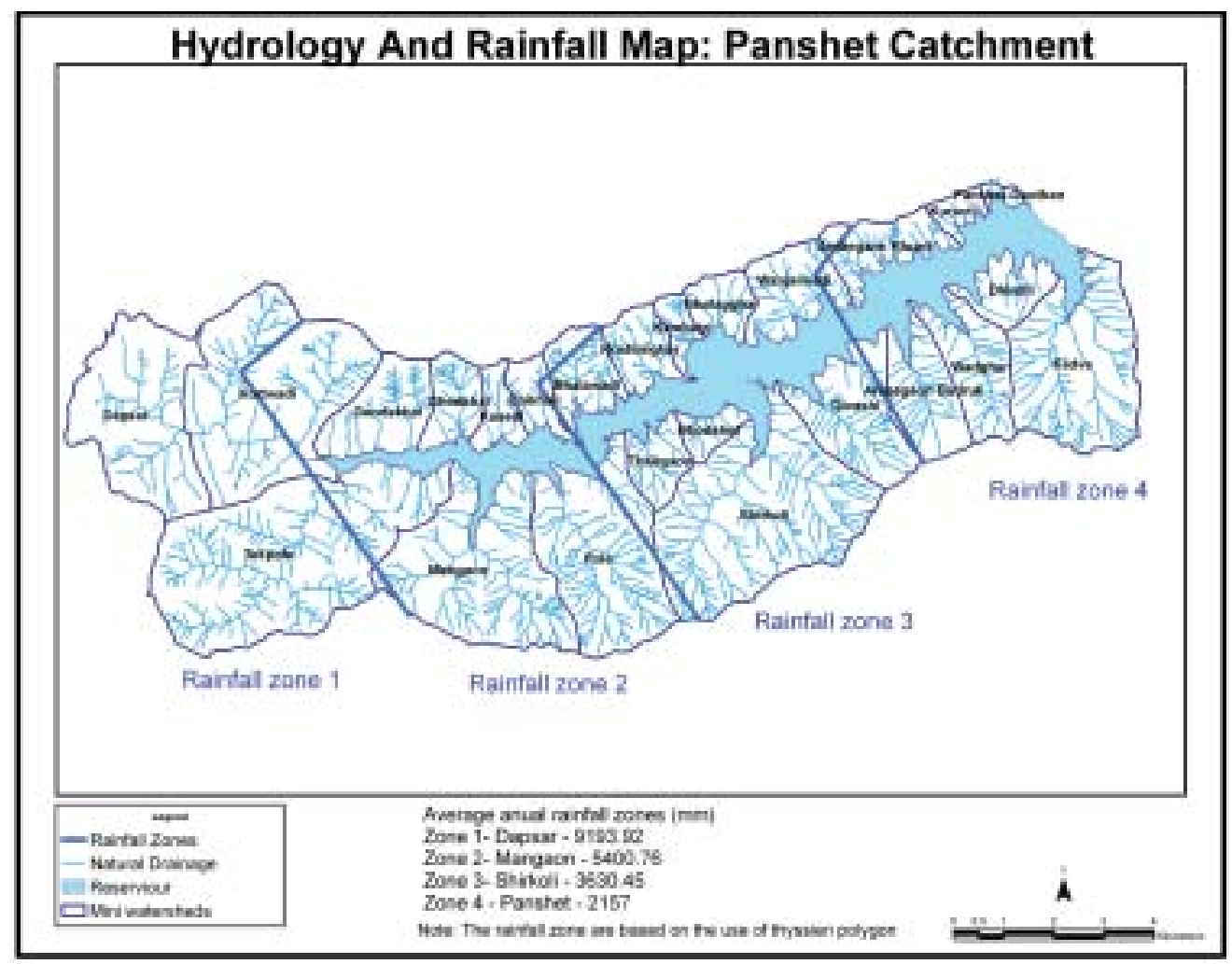

Figure 2: Villages and Rainfall Zones in the Panshet catchment

Table 1: Population by village

Villages surveyed

Panshet gaothan Ambegaon Khurd Kadve / Kadhve Kambegi Gondekhal Dapsare
1981 census Population Households
2011 census Population Households
2014 interviews Population Households

40-50 8-10

$90 \quad 10-12$

$1300 \quad 170$

50-60 10-12

$50-60 \quad 12$

$180-200 \quad 28$

Note :

- 1981 census data retrieved from (Gole, 1985) and (Brahme, 1986)

- 2011 census data retrieved from http://www.census2011.co.in/

- While Kadve's population has increased, it should be noted that, being situated in a side valley, Kadve was not displaced when the Panshet dam was built, unlike the other 23 villages in Panshet catchment area. 
The proportion of adults who have migrated out was 15\% during 1985 (Brahme, 1986). While we could not ascertain the number as of 2014, it is expected to be much higher.

2. Occupations : Historically, the main occupation in the Panshet catchment has been rain-fed agriculture. Traditionally, a three-year shifting cultivation pattern of Nachani (Eleusine coracana), followed by Varai (Panicum miliaceum) followed by Karale Teel (Guizotia abyssinica) was common. This pattern is still followed at very few places. By 1985, traditional rice cultivation was already on decline (Gole, 1985).

Rain-fed agriculture continues to be the main occupation of those who stay in the villages. Farmers take crops of Rice and Nachani, for household consumption and not for sale. This was recorded in 1985 too. Varai and Teel are also being grown but declining. No cash crops are present. Thus, income from agriculture has continued to be at subsistence levels or below it. Small farmers hold 4-5 acres of farmland while a relatively large land holding comprises of 10-15 acre. There are families holding even 1-2 acres, due to successive distribution of holdings across generations.

There is variation in the rice yield across farmers. Farmers mentioned yields of between 100 to $500 \mathrm{~kg}$ / acre. Based on our study, such variation could be attributed to (1) Destruction of crops by wild boar, (2) Varying use of fertilizers like Urea by farmers, and (3) Less productive agriculture by some farmers due to relatively less availability of labour. Further analysis on agricultural yields and income will need a detailed survey.

Other occupations or supplementary income sources, especially when no agricultural land is available, are : Rearing cattle to sell milk, Cultivating and selling Bamboo or household items from Bamboo, Rearing goat and sheep for self and for others, Working with the Gram Panchayat (Village Council), etc. Other than the larger villages like Kadve or Panshet Colony, there are no signs of specialist services like barbers, carpenters, etc.

Based on our assessment, these supplementary occupations are not highly profitable or have not displayed a significant capacity to enrich a household. Two examples may be useful :

- According to (Gole, 1985) a pole of Bamboo fetched Rs. 10-15 in the mid-80s, before it made its way to the Pune market. Our 2014 interviews show that Bamboo now fetches Rs. 80-90/pc for Meshi variety, Rs. 30-40/pc for Dhopil, and Rs. 100/pc for Kalak. Assuming an average price of Rs. 75/pc, we see a price increase of $5.7 \%$ per year over the last 30 years, which is below India's CPI inflation rate of $\sim 7 \%$ during this period, indicating the inability of this income source to help a household meet its expenses.

- The purchase rate for milk now stands at Rs. 30-32/ litre, relative to Rs. 2.5-3/litre in 1985. An average annual rise of $9 \%$, this is just slightly above India's inflation rate of $\sim 7 \%$ during this period. Moreover, milk production is often unprofitable due to the increasing scarcity of fodder and rising prices of cattle. Milk selling and distribution has to deal with rising fuel and transportation cost.

Relative to 1985, other natural resource-centric occupations have closed down. Coal making from forest wood has reduced significantly, as has harvesting of Hirda (Terminalia chebula) tree produce. In $1985,15 \%$ of the annual household income was estimated to come from mango and minor forest produce. In our study, sale of mango was not found to be significant. Similarly little evidence was recorded of sale of Jamun and other minor forest produce. Milkvending pastoralist households (dhangar) who reside on higher mountain slopes, have also declined, mostly to single digits in any given village.

Many locals also end up working as agri-labourers on others' fields when such work is available. It pays Rs. 250/day (male) and Rs. 200 (female) but they get a chance to work only a few times a year. It paid only Rs. 90-100/day (male) and Rs. 50 (female) until just a few years ago.

One new occupation has emerged: household help / laborers / watchman / cook and similar services for occupants of urban owners' bungalows. These jobs pay about Rs. 100/day and in some small villages nearly $10 \%$ of the population is engaged in them. Some other new occupations are in the land business, serving urban buyers for fulfilling their real estate related demands. These include real estate agents, building contractors, craftsmen, consultants, architects, and others. Most of this, however, is visiting population.

3. Land Use : (Brahme, 1986) mentions loss of top soil due to shifting cultivation and deforestation as a top problem for the catchment. This was rendering an increasing area unfit for cultivation in the 1980s and afterwards. Today, shifting cultivation continues to be the dominant method for agriculture and continues to affect land use. Compared to 1985, the following changes are observed:

a. In the absence of land share arrangements or 
manpower, farmers have left part of their land permanently fallow.

b. Where cultivation continues, the land under shifting cultivation as well as fallow period is declining as farmers are trying to maximize output. They are ready to use chemical fertilizers extensively. (Gole, 1985) mentions that in Zone 1, fallow period was already shortening even in the mid-80s to 2-3 years. It was 10-15 years and 5-9 years in Zone 2 and 3 respectively. This process of decline in shifting cultivation has continued.

c. Overall land under active agriculture has declined. As per (Brahme, 1986), 1044 hectares i.e. 2578 acres was the cultivated land area in 1986. According to our 2014 ecological and land use survey, 1571 acres is under paddy cultivation while 158 acre is under shifting cultivation of nachani, varai or teel. This is a total of 1729 acres i.e. $33 \%$ reduction in land under cultivation.

Some of the land has been claimed in land deals by urbanites - mostly for non-agricultural use. The land ownership transfers started in 1970s/80s, caught momentum in the mid-1990s and continues today. It is likely that some of these land parcels have changed hands multiple times among urban land investors with surplus wealth. Even as the landscape appears rural, it is partially composed of urban ownership.

Anecdotal evidence indicates that land prices in the Panshet catchment increased from a mere INR 2000/ acre in 1972 to INR 30 lakh/acre by 2011 (actual prices will vary based on location). This indicates an average annual increase of $20 \%$ over a 40 -year period. Neither the farmers' profits from their agricultural income, nor the supplementary occupations come close to providing the kind of wealth creation potential that land sale itself provides. Most such land sold to urbanites is converted to non-agricultural status to facilitate construction and is lost to agriculture or forest for good.

4. Cattle : (Gole, 1985) noted qualitative depletion of habitat but even then a large number of families had cattle. By 2014, several farmers had sold off cattle due to lack of fodder, lack of use, or increasing costs. In some villages less than $20 \%$ households now own cattle (1-6 each) which is a historic low. Indicative data is provided in Table 2.

Those in the milk business own relatively more cattle. Majority of the cattle are native species. Farther in the catchment, transport increases the cost of selling milk.

Grazing commons (gaayraan) which existed in some villages are now ignored or barren. Cattle feeds on forest department's land, private open lands, and agricultural residue. Hence, cattle grazing continue to be a cause of the degradation of the forest ecosystem.

5. Quality of soil (agricultural land) is declining overall, as per the study respondents. There is a relatively higher use of urea mix than before, while organic manure also continues to be used. Farmers are realizing that though yields have improved in short run due to use of chemical fertilizers, the crops have also become more prone to diseases and quality of soil will decline over the long term.

6. Vegetation around villages is on a general decline over the last 20+ years. e.g. The Hirda trees, once common in this area, are now almost completely exploited. Both (Gole, 1985) and (Brahme, 1986) had pointed out the ongoing loss of vegetation and plant life. This, in turn, has affected economic activity and resource potential in the catchment.

7. Forest food and resources: The villagers' food habits have increasingly grown to be similar to urban tastes. Nachni bhakri, rice, and varai (bhagar) formed the staple diet in 1980s (Brahme, 1986). Today, the consumption of wheat has significantly increased.

Apart from some forest vegetables during the monsoon season or the seasonal mangoes and jackfruit, no other forest food is consumed. Villagers are heavily dependent on the forest for fuel wood Karavanda, Kaarvi, Ain and if available Bor, being the

Table 2: Cattle population

$\begin{array}{llll}\text { Village } & & 1985 \text { study } & 2014 \text { study } \\ \text { Dapsare } & \text { Human population } & 187 & \\ & \text { Households } & 44 & \\ & \text { Cattle (excl. sheep/goat) } & 218 & \\ & \text { \% Cattle-owning households } & \text { NA } & 20 \% \\ & \text { Average Cattle/household } & 4.95 & 2-4 \\ \text { Ambegaon Khurd } & \text { Cattle (excl. sheep/goat) } & 310 & 40-50\end{array}$


plants of choice. A few of them make items of household use from bamboo as a side occupation. Awareness of medicinal plants is on the decline, except for places like Dapsare which are closer to Sacred Groves or away from town centers.

Villagers admitted to cutting fuel wood from all over the catchment except sacred groves. Our ecological survey points out that even some sacred groves are under a process of degradation. e.g. In Gondekhal, a small sacred grove (devrai) is adjacent to the village. Cattle-grazing is allowed in this sacred grove. Dapsare has a sacred grove adjacent to the village. The sacred grove is respected and cattle-grazing/cutting does not seem to be too common in it.

As urban land owners fence off their properties, access to fuel wood has decreased.

8. Schools: Some of the villages have nursery schools (Aanganwadis) and schools till $8^{\text {th }}$ grade, while some with lower population (e.g. less than 15 households) do not have any schools. Children from these villages have the option of walking to schools in nearby villages, which may be some distance away. The schools have teachers on government payroll. Due to the decline in population, the number of students enrolled is small. Absenteeism within teachers is also a problem. After $8^{\text {th }}$ grade, the only option is to study at schools at Panshet colony. Many such students commute daily, which is tiresome and time-consuming, because there is only one bus scheduled during the day from these villages to Panshet town. Some others live in hostels in the town, but they are expensive. Due to urban integration, many of the young families have migrated to Pune, Mumbai, and other cities, and their children are studying in city schools.

9. Amenities : There are no Primary Health Centers or Ration Shops in these villages, though they are a necessity for the villagers. In case of health emergencies, the patients either have to be taken to places like Panshet or Khanapur and there is a risk of patients dying due to the lack of transport. Most villages are now electrified, which was not the case during the 1985 study.

10. Community Bonds: Our interviewees also mentioned that urbanites and people from other villages buying land has disturbed the locals' confidence in agriculture. Traditional ways of collaboration have deteriorated or vanished. The expertise and the patience with the land is fading away.

The recent erratic nature of monsoon (partly due to climate change) has also affected their behaviour. As the monsoon period is often short or unpredictable, the tendency is "I need to focus on my field first; I will help others only if I have any time left!" The teamwork in agriculture has stopped. The earlier arrangement of helping on each other's' fields involved taking turns and not money. Now money is being paid so relationships have become transactional.

Locals are now increasingly dependent on their urban relatives for money - some of those who got educated have relatively higher salaries and this reduces importance of local agriculture even more.

The urban property owners have created jobs, but not too many. A typical new bungalow / farmhouse can generate at most 3-4 jobs in the form of cooks, cleaners, guards, etc. Several urban owners and developers are from outside Maharashtra and they bring household labour from other states. As such, locals may not be necessarily benefiting due to this development.

11. Income: Average annual income will vary within the villages of Panshet catchment, depending on the main and supplementary occupation, land holding, financial aid from city-based relatives, etc. A more detailed survey is warranted for a good estimate. However, focusing on the lower economic stratum those having 1-2 acres of land or no land, those who depend on the Public Distribution System for their daily food, those who depend on city relatives or on debt for any major financial needs - we felt that our interview data points to an income of Rs. 3,000-4,000 per month.

12. Problems identified by villagers: Villagers mentioned the following pain points during interviews :

a) Destruction of crops by animals like wild boar, monkeys, and barking deer.

b) Declining agricultural yields and degrading soil quality

c) Poor public transport and connectivity to Panshet and Pune. There is only one bus per day scheduled to go to Panshet.

d) Schools are not well managed. Students have to walk long distances wasting time.

e) Most children residing here can get education only till 8th/9th (that too in Panshet) and later have to work in menial jobs like labourers, drivers or unskilled computer work.

f) Farmers do not grow enough food to meet their sustenance needs. They have to buy food from the market or are dependent on aid sent by urban family members.

g) Transport costs have increased rapidly. Producing and selling to the city is increasingly expensive. 
h) Local governance bodies (gram-panchayats) are dominated by some families and may not hold regular meetings or pass information about government schemes to villagers.

Local communities in this region are seen to have a hand-to-mouth existence. There are daily struggles for food, fodder, and health services. They do not have major aspirations for local growth as their basic needs are not being met. Sometimes, their aspirations are not in harmony with local conditions. E.g. in Dapsare, villagers are unhappy because a nearby road connecting to Konkan cannot be built due to forest land reservations. They are also unhappy because the government has declared the area an Eco-Sensitive Zone and new construction activity is restricted. They feel this constrains 'development' of their area. They have no idea of what alterative growth models could be used.

\section{Changes observed relative to the 1985 study}

Salient comparisons with the 1985 study by Ecological Society may be useful :

- (Gole, 1985) wrote, "The average family residing in the Panshet catchment today barely earns enough to sustain itself. The agriculture they practice is primitive, less productive, and generally harmful to the environment. The cattle they keep also produce less, do not get enough nutrition, and are a drain on the time and energy of the family". The present study shows that these trends have either remained the same or worsened. Farmers are relying on chemical fertilizers to produce more. Soil quality has declined. The number of cattle have declined significantly. The farmer of the Panshet catchment seems to be more or less at the same place socio-economically as 30 years ago.

- (Gole, 1985) also noted "With the disappearance of the forest, their sources of income are also fast declining". This process has worsened. Not only income, but even knowledge of the forest and its produce has shown a decline from 1985 to 2014. The forest department has taken efforts to protect the forests, but a symbiotic relationship between the forest and people or preservation of any significant ecological niche (e.g. in food or livelihood) could not be seen. With a few exceptions, even the sacred groves have suffered from degradation. There is little interest among villagers to conserve local nature other than the sacred groves.

- (Gole, 1985) noted, "The people...have to fall back on selling off remaining trees to charcoal merchants and to rely heavily on government subsidies". The degradation of the forest has continued. Charcoal was a temporary cash cow back then. Today, real estate is the cash cow. A farmer cannot justify continued productive use of land for agriculture when urban buyers offer several times his annual income for the same piece of land, especially in face of all the hardships in doing agriculture in the Western Ghats.

- (Gole, 1985) mentions an average income of Rs. 300/ month in the catchment. Our estimate of income of Rs. 3000-4000/month for the lower economic stratum represents a 10 -fold increase in 30 years, or $8.8 \%$ per year. This is only $1.8 \%$ per year after adjusting for inflation. Moreover, it is much lower than India's average monthly income of Rs. 5130 in 2011-12, indicating the lack of economic opportunity to those in the lower rungs of these communities. Those who do not have access to wealth-creating land are increasingly dependent on their city-based relatives.

- There is a depressed or negative feeling among most of the villagers who have been residing here. Decades of lack of facilities and poor governance have created this depression (e.g. healthcare, education, transport). Their next generation has little by way of development options and may need to migrate to cities.

- For new occupations and ideas, lack of manpower may prove to be an impediment as younger people have migrated out.

(Gole, 1985) envisioned an Eco-Development Plan for the catchment. His key recommendations are summarized in Annexure 1. Over the 30 years since this unique Eco-Development Plan was proposed, the recommendations have not received the attention they deserve from policy makers.

- As for recommendation \#1 in Annexure 1, works related to soil conservation have happened sporadically based on various government initiatives. Plantations were traditionally of exotic species. Of late, attention is being given to indigenous flora for plantations on governmentowned land, but we do not see significant evidence of this in the Panshet catchment.

- As for recommendation \#2 in Annexure 1, our study found that the extent of shifting cultivation has reduced, but this is largely a function of farmer migration to cities, land sales to urbanites, and reduction in cultivation as an occupation. There is no policy thrust behind reducing shifting 
cultivation through an awareness campaign or local measures.

- As for recommendation \#7 in Annexure 1, some tourism activities have started, but they are largely driven by local and city-driven entrepreneurship, and not due to a supporting environment created by policy makers, neither can they be guaranteed to be environment-friendly. E.g. Such tourism creates waste like plastic bags and plastic water bottles, which chokes up ecosystem flows. A more systematic plan of job creation, while keeping sustainability in mind, needs to be designed and practiced in the Panshet catchment. Case studies like Velas (Nulkar, 2014) would provide useful inputs for such a plan.
Other than the above, there was no follow-up by the authorities on any of the recommendations. If they were actually implemented, these recommendations had the power to mitigate problems and pain points that we see today in 2014, as shown in Table 3.

30 years of forest restoration and conservation work, if facilitated by policy makers, would have created several ecologically rich pockets in the catchment, with significant economic returns to local communities.

In summary, strong and timely action on all the recommendations would have averted the ecological erosion, overdependence on urban economy, migration, and subsistence-level life of locals that we observed in present-day Panshet.

(Gole, 1985) had also warned: "...this eco-

\section{Table 3}

\begin{tabular}{|c|c|}
\hline Pain Point (2014) as told by interviewees & $\begin{array}{l}\text { (Gole, 1985) recommendations which, if implemented, } \\
\text { could have potentially mitigated the problem } \\
\text { (numbering from Annexure 1) }\end{array}$ \\
\hline $\begin{array}{l}\text { Destruction of crops by animals like wild boar, } \\
\text { monkeys, and barking deer. }\end{array}$ & $\begin{array}{l}\# 4,6,8 \text {. Creation of the sanctuary, indigenous plantation, } \\
\text { and protection of local forest would protect wild animals' } \\
\text { habitat and there would be less chance of them } \\
\text { wandering to fields }\end{array}$ \\
\hline $\begin{array}{l}\text { Declining agricultural yields and } \\
\text { degrading soil quality }\end{array}$ & $\begin{array}{l}\# 1,2,6,11 \text { would have a direct impact in soil } \\
\text { conservation }\end{array}$ \\
\hline $\begin{array}{l}\text { Poor public transport to connectivity to Panshet } \\
\text { and Pune. There is only one bus per day } \\
\text { scheduled to go to Panshet. }\end{array}$ & $\# 17$ \\
\hline $\begin{array}{l}\text { Schools are not well managed. Students have to } \\
\text { walk long distances wasting time. }\end{array}$ & $\# 9$ \\
\hline $\begin{array}{l}\text { Most children residing here can get education } \\
\text { only till } 8 \text { th/9th (that too in Panshet) and later } \\
\text { have to work in menial jobs like labourers, } \\
\text { drivers or unskilled computer work. }\end{array}$ & $\begin{array}{l}\# 4,5,7,8,9,10 \text { - all of these have strong emphasis on } \\
\text { local employment, vocational skills (including natural } \\
\text { resource management) and would have averted both the } \\
\text { decline in quality employment and migration to cities }\end{array}$ \\
\hline $\begin{array}{l}\text { Farmers do not grow enough food to meet their } \\
\text { sustenance needs. They have to buy food from } \\
\text { the market or are dependent on income sent by } \\
\text { urban family members. }\end{array}$ & $\begin{array}{l}\# 3,4,5,10 \text {-indigenous plantations, horticulture, and } \\
\text { agro-forestry would have created a path towards } \\
\text { supplementary income and enrichment of farmers. }\end{array}$ \\
\hline $\begin{array}{l}\text { Transport costs have increased rapidly. Producing } \\
\text { and selling to the city is increasingly expensive. }\end{array}$ & $\begin{array}{l}\text { Virtually all the suggestions are about creating a strong } \\
\text { local economy. Goods exported to the urban economy } \\
\text { (e.g. fruit and timber) would carry enough pricing power } \\
\text { to sustain rise in transport costs. For other services like } \\
\text { nature tourism, urban customers would actually travel to } \\
\text { Panshet. }\end{array}$ \\
\hline
\end{tabular}


development approach does not give room to stock measures of economic improvement such as road-building and industrialization...such measures...may do incalculable harm to the ecology of the region as well as its residents." These grave concerns have unfortunately come true. What we observe today in the Panshet catchment is a steady march towards urbanization through land sales, plotting, conversion of land to non-agriculture use and farm-house schemes, resulting in an increase in land movement, roads and vehicle activity.

(Brahme, 1986) had also proposed a similar ecodevelopment plan. In addition, it had outlined specific redevelopment programs for the villages of Kuravati, Shirkoli and Mangaon.

\section{Discussion and Recommendations}

As the Western Ghats is a global biodiversity hotspot, the Government of India appointed the Western Ghats Ecology Expert Panel (WGEEP), which submitted its report in 2011, widely known as the Madhav Gadgil report (Gadgil, 2011), and in 2013, the High Level Working Group on Western Ghats (HLWG), known as the Kasturirangan report (Kasturirangan, 2013).

As a result of these studies, on March 10, 2014, the Ministry of Environment and Forests published declaration No. 624, which defined eco-sensitive zones in W. Ghats, the restrictions on development in these eco-sensitive zones, and the villages in various districts which come under eco-sensitive zones. As per our knowledge, the following villages from the Panshet catchment, all belonging to Velhe taluk of Pune district, are now under an eco-sensitive zone: Dapsare, Gholapghar, Balaodi, Kambegi, Kadave, Chikhali, Ambegaon BK, Kurtwadi, Kasedi, Gondekhal, Givashi, Ghodshet, Shirkoli, Tekpole, Mangaon, Pole.

Thus, a large part of the Panshet catchment is now under an eco-sensitive zone and the following activities are prohibited :

- Mining

- Thermal power plants

- Polluting industries designated by state or central pollution boards

- Construction/development projects amounting to $>20,000$ sq.m. of construction foot print

While this will benefit the environment, the regulation still leaves room for a large amount of urban development, including farmhouses, resorts, and roads. It is unfortunate that land sales to urbanites has become the main and only tool for wealth creation in this area. We believe that urban lifestyle and interference is likely to be a key cause of stress on ecosystems in this region going forward.

Considering this, it may be useful to evaluate the following approach going forward.

1. A landscape ecological approach is strongly recommended to be followed for the Panshet catchment and its surrounding areas. Many of these are similar dam catchments under ecosensitive zones, with similar combination of ecological stresses and socio-economic challenges outlined above.

2. The landscape ecological approach should be multi-lateral, involving local and state government agencies, NGOs, local population, urban land owners in these areas, subject matter experts from academic and research institutes, and philanthropists. Such multi-lateral involvement will ensure that all stakeholders' interests are considered and a common vision for sustainable development is created for the catchment.

3. The specific recommendations of (Gole, 1985) on a comprehensive Eco-Development Plan, inclusive of a Wildlife Sanctuary, holds enormous merit in our opinion. If a sanctuary is not possible due to people displacement or land ownership issues, as much statutory and community protection of forests should be achieved as possible in the current situation.

4. A quasi-government entity, similar to the Catchment Authority proposed by (Gole, 1985) would still be very useful. Such an entity should take environmental sustainability, as defined by the Burtland Commission, as a founding principle. Nature conservation and restoration programs should be conceived and executed by this authority. Such a Catchment Authority should be an independent authority funded by the state government, Corporate Social Responsibility (CSR) programs, and from tax collections from locals, urban land owners, and tourists. It should work closely with the irrigation department, the forest department, and local village councils to impart the vision of a sustainable catchment.

5. Conservation programs must provide clear economic benefits to the locals to be effective. This would include short run benefits (e.g. monetary compensation, education, job-oriented training, job creation, inclusive decision-making in conservation planning) and long run advantages (sustainable extraction of forest resources, sustainable agriculture, direct marketing to consumers of agriculture and forest produce, wellplanned housing, reliable water supply, 
healthcare).

6. Urban citizens should volunteer in large numbers to make the conservation programs successful.

7. Primary and secondary schools in the Panshet catchment should receive educational resources, financial aid, and quality teachers with support from NGOs, government, philanthropists, and volunteers. Such schools should offer an ecoeducation stream linked to local ecosystems, which includes local biodiversity, forest conservation, natural resource management, sustainable agriculture, and basic vocational skills.

8. Urban land owners in these villages will be key influencers of this landscape as well as its conservation. The above-mentioned authority should take this into cognizance. It should catalyze nature conservation among urbanites and locals alike. E.g. Ideas like private sanctuaries on collective land of urban owners should be implemented. Such an initiative is already in progress by Oikos, an ecological consultancy, near Shirkoli village in the catchment.

Below we offer a set of new vehicles and ideas, mainly by way of example, to implement the above recommendations :

- Model Eco-Sensitive Zone Initiative for Panshet (MESZIP) : This should be an initiative of NGOs, local citizens, and urban volunteers who are interested in restoring nature while achieving sustainable economic development in the Panshet catchment. Their aim would be to demonstrate that Panshet catchment can become a Model EcoSensitive Zone and not go by way of urbanized hill stations like Lonavala over the next 2-3 decades. They should involve stakeholders like real estate industry, bureaucrats, forest dept., irrigation dept., farmers, land owners, schools, housewives, etc and hold ongoing sustainability education workshops for them. One of the outputs from MESZIP could be to work with NGOs and academics to evolve a Landscape Ecology Plan for the Panshet catchment (LEPP) in a scientific yet socially sensitive manner. They should also develop long-term CSR relationships with corporates who would be willing to fund ongoing conservation and restoration programs in the catchment. A successful example of such a working group is Jeevitnadi, Pune, which works on the cause of rivers.

- Landowner-Conservators' Collective (LCC): This should be primarily composed of urban land owners who have bought or considering buying land in the Panshet catchment and who are interested in conserving nature. A few of them would have to play the role of a catalyst and bring everyone together. In collaboration with MESZIP and NGOs, they would develop conservation and restoration plans for patches of lands owned by them. This should fit within the LEPP. The LCC should facilitate collaboration on larger-scale initiatives like private sanctuaries, expanding community conserved areas, sharing of grass and forest output with locals in planned manner, etc.

- Incubator for Sustainable Local Economy (ISLE) : This incubator should be physically in the Panshet catchment with business and funding connections to Pune and promote ecological entrepreneurship, agro-forestry, horticulture, organic farming, simple eco-tourism, etc. Local youth, homemakers, and farmers would generate supplementary income through such opportunities and raise their annual income.

- Reverse Migration Program (RMP) : The declining population in the Panshet catchment poses a challenge in executing conservation programs even if funds are available. The increasing migration to cities creates a dependence on the urban economy and a feeling of emptiness locally. To break through this, a Reverse Migration Program should be considered. The study found that Panshet residents migrating to cities had low skill sets and had to choose low paying jobs, subsequently lowering their quality of life. Such people should be actively supported in moving back to the Panshet catchment. They should receive initial subsidies and cultivate family land or explore one of the above-mentioned entrepreneurship opportunities. Moreover, many city-dwellers are tired of city life and want to quit to get closer to nature. A pathway for them in terms of land purchase, guidance in conservation, agroforestry, horticulture, or non-profit work could be facilitated under the RMP.

- Pune Volunteers for an Eco-Sensitive Panshet (PVEP) : The main beneficiaries of the Panshet dam are city dwellers in Pune who receive $24 \times 7$ supply of high-quality water. It would be worthwhile for them to give back by creating a legion of volunteers to donate labour, time, and funds (e.g. crowdsourcing) for conservation, education, and entrepreneurship activities specifically in the Panshet catchment. There are several examples of urban volunteers contributing successfully to nature education, indigenous plantation, exotic species control, Sacred Grove protection, etc in the catchment. 
- Similar action vehicles could be considered for other dam catchments in W. Ghats where similar problems exist. It will be ideal to form a network of people and groups working on sustainable dam catchments in W. Ghats and their restoration. Such a network would facilitate research and field study, exchange of ideas, assessment of common problems, and support for their resolution.

To be effective, programs suggested above should work in collaboration with each other.

A landscape-based ecosystems management approach, government support for conservation, and a stop to further roads and real estate development will save this landscape. A good governance approach, with local and urban citizen participation is also essential. If nature conservation and restoration programs are designed to reward the local populations meaningfully and also create better soft infrastructure for the community, these could prove to be saviors of the region.

\section{Acknowledgements}

The study in Panshet catchment was supported by the Small Grants Program of Global Forest Watch.

\section{Annexure 1}

\section{A summary of Eco-Development plan recommendations from (Gole, 1985)}

1. Soil conservation measures on an urgent basis: Bunding and terracing of slopes, planting grasses that will hold the soil and provide nutritive fodder, planting suitable vegetation that will provide a wind-break and cover the ground against the impact of rain drops, etc.

2. As much reduction as possible in shifting cultivation and grazing as it results in forest degradation and accelerates soil erosion

3. Replacing cereal agriculture (which is not compatible with soil conservation) by horticulture for production of wood for fuel and timber.

4. Plantations exclusively with indigenous species, e.g. Terminalia chebula, which can provide economic returns as well as a link in the ecological food chain.

5. Plantations of high-yielding fruit like cashew and spices with careful management

6. Maintenance of the semi-evergreen and moist deciduous forests to support habitat and scenic beauty
7. Recreation activities that do not harm the habitat (e.g. hiking, angling, birdwatching, nature study tours) to generate local employment. While encouraging such tourism and creating related infrastructure (e.g. camping areas and tents), urban-style amenities like car parks, sports facilities, or video parlours should be strictly avoided. Boating should exclude power boats. Nature Information Centers should be created near select sacred groves like Mangaon, Shirkoli, and Gondekhal. These tourist activities, though seasonal, will create local employment. Transport to such locations would be by motor launch, thus avoiding the need for cars, larger vehicles, or any widening of roads.

8. A wildlife sanctuary spread over 5896 acres in the ecologically rich yet fragile area near the crestline, after relocation of its inhabitants by providing better opportunities elsewhere. This would protect the forest and also provide stability to the dam catchment. Such resettlement was possibly in theory, on land available with the Irrigation Dept. This displaced population would be given compensation and also supported to own cattle and form a milk co-operative.

9. Facilities like addition of a technical and vocational training school, hospital, consultancy for cottage industries, bee-keeping, sericulture, and dairy development, and other agro-based vocations.

10. Agro-Forestry Experimental Stations preferably on barren land owned by Forest Dept. or Irrigation Dept. Such land could be leased to voluntary agencies to develop experimental farm-cumdemonstration center for local cultivators. This would also include a nursery for local plant saplings, improved forage or fuel wood at cheaper rates, etc.

11. Raise overall vegetative cover by raising plantations of medicinal plants, quick-growing trees for fuel wood and timber, fruit trees, economically important flowering plants, improved varieties of grasses. Set up programs for such re-forestation on private land.

12. Monetary incentives for a villager where at least $25 \%$ families give up shifting cultivation, stallfeed cattle, and offer some land for agro-forestry. Such incentives could include Rs.300/month (1985) in the form of subsidies for grain, other necessary articles, etc.

13. Creation of a new statutory authority called Catchment Area Development Authority to tackle 
the problems of eco-development not just for this dam but for all such dam catchments (in W. Ghats and other mountains)

14. Identification of Sacred Groves areas within land held by Forest Dept and strict protection for such land. This would gradually lead to vegetational climax in such sacred groves, aiding revival of indigenous forest cover.

15. Initiate a separate Forest Range with a Range Forest Officer interested in flora and fauna of the catchment with adequate amount of staff and guards. This would also create local employment.

16. Careful definition of rights of Dhangar pastoralists on collection of wood and produce from forests.

17. Transport of wood and charcoal by trucks should be banned. On the other hand, local residents should get good bus service.

18. The total cost of the above Eco-Development plan was estimated in detail and it came out to Rs. 74 lacs (in 1985 rupees) or Rs. 1607/person over a five-year period. This was a reasonable investment to achieve indigenous plantation on 4900 acres of private holdings, to protect 4384 acres of forest land belonging to the Forest Dept., to create a new wildlife sanctuary, and to create a vibrant natural-resource-based local economy. This healthy local economy would result in doubling of the local per-capita income. Levels of education and vocational skills were also expected to go up.

\section{References}

- Gole, Prakash and Tetali, P. (1985). An enquiry into the status of animal and plant life in the critical areas of Western Ghats in order to evolve a plan to conserve their biological diversity, Vol. 1, Ecological Society

- Brahme, Sulabha and Tetali, P. (1986), Economic and ecological impact of Panshet reservoir : A study in problems and eco-development alternative, Gokhale Institute of Politics and Economics

- Report of the Western Ghats Ecology Expert Panel (WGEEP), 2011, Gadgil, M., et. al., Ministry of Environment and Forests, Government of India. Last retrieved on 21.11.2015 from http:// www.moef.nic.in/downloads/public-information/ wg-23052012.pdf

- Report of the High Level Working Group on Western Ghats (HLWG), 2013, Kasturirangan et. al., Ministry of Environment and Forests Government of India, 2013

- Nulkar, G., Lessons from Velas : Assessment of Ecotourism as a Model for Conservation in Konkan, Journal of Ecological Society, v. 26 and 27 (2013-14), pp. $71-82$ 